\title{
Analisis Kesulitan Guru Biologi Mengajar Di SMA Negeri Kota Lubuklinggau Selama Masa Pandemi Covid-19
}

\section{Nevi Yantari ${ }^{1 *}$, Mareta Widiya $^{1}$, Sepriyaningsih $^{1}$}

${ }^{1}$ Program Studi S-1 Pendidikan Biologi, Jurusan Pendidikan Matematika dan Ilmu Pengetahuan Alam, STKIP PGRI Lubuklinggau, Indonesia

\section{*Email: neviyantari6@gmailcom}

\section{Info Artikel}

Diterima: 17 Februari 2021
Direvisi: 1 November 2021
Diterima
untuk diterbitkan: 4 November
2021

\section{Keywords:}

Kesulitan guru biologi, pembelajaran daring

\begin{abstract}
Abstrak
Penelitian ini bertujuan untuk mengetahui kesulitan guru biologi mengajar di SMA Negeri Kota Lubuklinggau pada masa pandemi Covid-19. Metode penelitian ini menggunakan pendekatan kualitatif deskriptif. Teknik pengumpulan data ialah menggunakan observasi, wawancara, angket, dan dokumentasi. Populasi pada penelitian ini adalah seluruh guru biologi di SMA Negeri 1, 2, 4, 5, 6, 7, dan 8 Kota Lubuklinggau. Sampel pada penelitian ini adalah 15 guru biologi dari SMA Negeri Kota Lubuklinggau. Berdasarkan hasil analisis kesulitan dibagi menjadi lima aspek indikator (media, motivasi, sikap, kreativitas, dan sarana prasarana). Hasil persentase setiap SMA Negeri Kota Lubuklinggau telah mencakup dari lima aspek indikator, guru SMA Negeri 1 (14\%), guru SMA Negeri 2 (36\%), guru SMA Negeri 4 (31\%), guru SMA Negeri $5(27 \%)$, guru SMA Negeri $6(28 \%)$, guru SMA Negeri 7 (31\%), dan guru SMA Negeri 8 (22\%). Dapat disimpulkan setiap guru biologi di SMA Negeri Kota Lubuklinggau mengalami sedikit kesulitan dalam proses pembelajaran daring selama masa pandemi Covid-19. Kesulitan yang paling rendah terdapat pada guru SMA Negeri 1 Lubuklinggau dengan persentase 14\% dan SMA Negeri 2 Kota Lubuklinggau memiliki persentase kesulitan paling tinggi sebesar $36 \%$.
\end{abstract}

(C) 2021 Universitas Bengkulu. This is an open-access article under the CC-BY license (https://creativecommons.org/licenses/by/4.0)

\section{PENDAHULUAN}

Tahun 2019 digemparkan dengan adanya identifikasi tentang virus baru yaitu Coronavirus $(\mathrm{CoV})$ atau disebut juga dengan Covid-19. Coronavirus (CoV) ini merupakan penyakit yang menular karena disebabkan oleh adanya sindrom pernapasan akut coronavirus 2 (Severe Acute Resipiratory syndrome coronavirus 2 atau SARSCoV 2).Virus ini dapat menyerang hewan dan ketika virus ini menyerang manusia akan menyebabkan penyakit infeksi saluran pernafasan, 
contohnya seperti gejala flu, MERS (Middle East Respiratory Syndrome) dan SARS (Severe Acute Resipiratory Syndrome). Covid-19 pertama kali ditemukan di Wuhan, Hubei, China pada tahun 2019 (World Health Organization, 2019). Wabah pandemi Covid-19 memberikan dampak yang cukup besar di berbagai bidang terutama dalam bidang pendidikan (Ahmad,2020). Virus Covid-19 ini membuat para siswa dan guru harus melakukan sistem pembelajaran daring (Handirini \& Wulandari, 2020).

Pemerintah telah membuat adanya kebijakan-kebijakan yang tidak merugikan bagi masyarakat, dari siswa sampai mahasiswa dalam pendidikannya dengan pembelajaran dilaksanakan di rumah dengan menggunakan daring atau belajar secara online (Amar's, 2020). Dunia pendidikan selalu mengalami perkembangan seiring dengan perkembangan zaman, begitu pula dengan pendidikan di Indonesia yang terus mengalami perkembangan (Riastuti, 2021).

Dampak dari Covid-19 ini berpengaruh bagi dunia pendidikan telah diakui oleh organisasi pendidikan UNESCO yang merupakan singkatan dari United Nations Educational, Scientific and Cultural Organization, tugasnya meliputi promosi tentang pendidikan, sains dan budaya serta komunikasi dan informasi. Indonesia sebagai salah satu negara yang mengalami pandemi ini juga merasakan kegelisahan yang menyebabkan pemerintah harus mengambil keputusan sulit, di antaranya adalah seluruh aktivitas menggunakan metode online atau jarak jauh (Amirullah, 2020).

Pada saat pandemi Covid-19 yang terjadi di Indonesia menyebabkan sistem pendidikan melakukan penyederhanaan kurikulum dengan mengurangi kompetensi dasar (KD) untuk setiap mata pelajaran (Riastuti, 2021). Sesuai dengan adanya anjuran dari pemerintah melalui Kementerian Pendidikan dan Kebudayaan atau disebut juga Kemendikbud terkait adanya kedaruratan Covid-19 adanya surat Edaran Nomor 2 Tahun 2020, yaitu tentang Pencegahan dan Penanganannya di lingkungan Kemendikbud serta adanya pula surat Edaran Nomor 3 Tahun 2020 tentang Pencegahan Covid-19 pada Satuan pendidikan. Pemerintah mendorong para guru untuk tidak menyelesaikan semua materi yang ada dalam kurikulum (Menteri Pendidikan, 2020).

Ada beberapa jenis pembelajaran daring yaitu sebagai berikut, knowledgebase, online support, pelatihan asinkron, pelatihan sinkron, dan pelatihan hybrid atau blended (Basilaia \& Kvavadze, 2020). Pembelajaran biologi merupakan pembelajaran yang terkesan sulit dan banyak hafalan (Jayawardana dkk, 2020). Biologi merupakan cabang ilmu pengetahuan yang mempelajari tentang makhluk hidup, seperti hewan, manusia, dan tumbuhan. Media yang digunakan dalam pembelajaran biologi ini guru menggunakan aplikasi berupa whatsapp, goggle classroom, dan zoom meeting (Supriyatin, 2020). Dengan menggunakan media teknologi tersebut dapat mengurangi interaksi antara siswa, guru, kepala sekolah, kurikulum, dan lain staf sekolah lainnya (Saifulloh, 2020).

Belajar dan mengajar adalah dua konsep yang tidak dapat dipisahkan satu sama lain. Dua konsep ini selalu menjadi terpadu dalam suatu kegiatan, dimana adanya interaksi guru dengan siswa bahkan interaksi siswa dengan siswa pada saat pembelajaran berlangsung (Jayawardana, 2020). Adanya faktor-faktor ketika pembelajaran berlangsung selama masa pandemi Covid-19, yaitu faktor sarana dan prasarana, faktor metode pembelajaran, dan penguasaan materi. Dapat diketahui permasalahan penelitian ini adalah bagaimana kesulitan yang dihadapi oleh guru biologi dalam mengajar di SMA Negeri Kota Lubuklinggau pada masa pandemi. Penelitian ini bertujuan untuk mengetahui kesulitan yang dihadapi oleh guru biologi dengan adanya indikator media, sikap, motivasi, kreatifitas, dan sarana prasarana dalam mengajar di SMA Negeri Kota Lubuklinggau pada masa pandemi.

\section{METODE}

Metode penelitian yang akan digunakan dalam penelitian ini adalah metode yang bersifat deskriptif dengan pendekatan kualitatif. Populasi dalam penelitian ini adalah seluruh Guru SMA Negeri Lubuklinggau berjumlah 15 guru dari 7 SMA Negeri Lubuklinggau. Purposive sampling adalah teknik pengambilan sampel dengan pertimbangan tertentu. Sampel yang diambil pada penelitian ini hanya guru biologi berjumlah 15 di setiap SMA Negeri kota Lubuklinggau. Teknik 
pengambilan data pada penelitian ini adalah data kualitatif berupa deskripsi dari hasil perhitungan skor yang diperoleh dan disesuaikan dengan kriteria yang telah ditentukan. Jenis data merupakan data primer yang diperoleh dari pengamatan langsung di lapangan dengan menggunakan pengamatan observasi, angket, dan wawancara, sedangkan data sekunder adalah data yang diperoleh dari data latar belakang pendidikan guru Biologi di SMA Negeri Kota Lubuklinggau. Instrumen dalam penelitian ini menggunakan angket yang terdiri 19 item pernyataan dan terdiri dari lima indikator yaitu; media, sikap, motivasi, kreativitas, dan sarana prasarana. Skala yang digunakan yaitu skala Likert yang terdiri dari lima altenatif jawaban, yaitu sangat setuju, setuju, ragu-ragu, tidak setuju, dan sangat tidak setuju.

Prosedur analisis data pada penelitian kualitatif dilakukan sejak memasuki lapangan dan selesai dari lapangan. Analisis data menjadi pegangan selanjutnya dan lebih difokuskan selama berada di lapangan pada saat pengumpulan data, penelitian ini memilih menggunakan analisis model Miles dan Huberman yaitu: Reduksi data, penyajian data, menarik kesimpulan dan angket. Teknik analisis data yang digunakan dalam penelitian ini adalah analisis deskriptif dengan menggunakan persentase berikut ini:

$$
\mathrm{P}=\frac{n}{N} \times 100 \%
$$

Keterangan:

$\mathrm{n}=$ jumlah skor yang diperoleh responden

$\mathrm{N}=$ jumlah skor yang semestinya diperoleh responden

$\mathrm{P}=$ persentase

Menghitung persentase rata-rata untuk setiap aspek, dengan rumus:

Persentase rata-rata $=\frac{\text { jumlah } \text { skor } \text { yang didapat }}{\text { jumlah } \text { responden }}$

\section{Tabel 1}

Kriteria Deskriptif Persentase Angket

\begin{tabular}{ll}
\hline Persentase & Kriteria \\
\hline $81-100$ & Tinggi Sekali \\
$61-80$ & Tinggi \\
$41-60$ & Cukup \\
$21-40$ & Rendah \\
$0-21$ & Rendah Sekali \\
\hline
\end{tabular}

(Arikunto, 2013)

\section{HASIL DAN PEMBAHASAN}

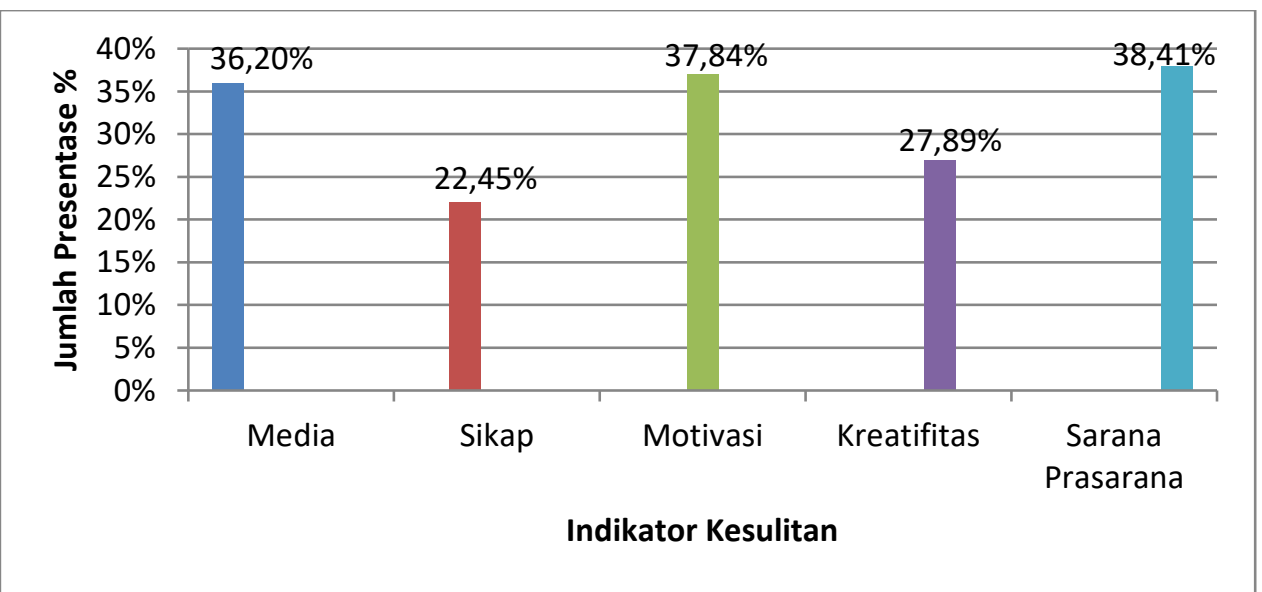

Gambar 1. Diagram Batang Persentase Kesulitan Guru Biologi di seluruh SMA Negeri Kota Lubuklinggau Berdasarkan gambar 1 diagram batang hasil penelitian dapat diketahui bahwa guru mempunyai sedikit kesulitan pada media sebanyak 36,20\% yang disebabkan beberapa guru belum 
mampu mengoperasikan komputer dengan baik untuk menggunakan media. Pada indikator sikap sebanyak $22,45 \%$ guru sedikit kesulitan saat adanya hambatan dalam menemukan metode atau cara agar tidak merasa bosan saat proses pembelajaran daring. Pada indikator motivasi yakni 36,84\% guru mengalami kesulitan saat memberikan materi ke peserta didik yang disampaikan sehingga guru harus memberi pemahaman dan reward agar siswa tetap aktif selama pembelajaran berlangsung. Pada indikator kreativitas sebanyak 27,89\% guru merasa kesulitan saat mengatasi permasalahan siswa yang sulit dalam memahami materi pembelajaran yang diberikan. Pada indikator sarana prasarana sebanyak $38,41 \%$ guru merasa kesulitan saat hilangnya jaringan internet yang membuat proses pembelajaran daring kurang maksimal.

\section{Tabel 2}

Kesulitan Pada Indikator Media

\begin{tabular}{lcc}
\hline \multicolumn{1}{c}{ Pertanyaan } & Persentase & Kriteria Hambatan \\
\hline $\begin{array}{l}\text { Guru dapat mengakses internet dengan baik dalam proses } \\
\text { pembelajaran daring }\end{array}$ & $42,10 \%$ & Sangat Setuju \\
$\begin{array}{l}\text { Guru dapat mengoperasikan komputer } \text { atau laptop dengan } \\
\text { baik }\end{array}$ & $29,47 \%$ & Setuju \\
$\begin{array}{l}\text { Guru menggunakan aplikasi tertentu dalam melakukan } \\
\text { proses pembelajaran daring }\end{array}$ & $37,89 \%$ & Setuju \\
$\begin{array}{l}\text { Guru menggunakan media pembelajaran berbasis daring } \\
\text { Guru menggunakan RPP ketika hendak melakukan } \\
\text { pembelajaran daring }\end{array}$ & $29,47 \%$ & Setuju \\
Rata-rata & $42,10 \%$ & Setuju \\
\hline
\end{tabular}

Berdasarkan data dari Tabel 2 menunjukkan bahwa guru biologi merasa sedikit kesulitan dari indikator media dengan persentase sebesar 36,20\% dengan kriteria penilaian rendah. Guru dapat mengendalikan sedikit kesulitan yang dihadapi saat proses pembelajaran daring seperti jaringan, aplikasi yang digunakan saat menentukan media pembelajaran, dan saat menggunakan komputer atau laptop.

\section{Tabel 3}

Kesulitan Pada Indikator Sikap

\begin{tabular}{|c|c|c|}
\hline Pertanyaan & Persentase & Kriteria Hambatan \\
\hline $\begin{array}{l}\text { Guru kesulitan menemukan metode belajar yang } \\
\text { menyenangkan pada proses pembelajaran daring }\end{array}$ & $25,26 \%$ & Setuju \\
\hline $\begin{array}{l}\text { Guru mengalami hambatan ketika proses pembelajaran } \\
\text { daring }\end{array}$ & $23,15 \%$ & Setuju \\
\hline Guru merasa bosan dengan adanya pembelajaran daring & $21,05 \%$ & Setuju \\
\hline $\begin{array}{l}\text { Guru dapat berkomunikasi dengan baik kepada siswa ketika } \\
\text { pembelajaran daring sedang berlangsung }\end{array}$ & $29,47 \%$ & Setuju \\
\hline $\begin{array}{l}\text { Guru mengalami hambatan dalam membangkitkan motivasi } \\
\text { belajar siswa dimasa covid-19 saat ini }\end{array}$ & $21,05 \%$ & Setuju \\
\hline $\begin{array}{l}\text { Guru mengalami hambatan dalam alokasi waktu dalam } \\
\text { pembelajaran daring }\end{array}$ & $14,73 \%$ & Setuju \\
\hline Rata-rata & $22,45 \%$ & Rendah \\
\hline
\end{tabular}

Berdasarkan data dari Tabel 3 menunjukkan bahwa guru biologi di SMA Negeri Kota Lubuklinggau merasa kesulitan dari indikator sikap dengan persentase sebesar $22,45 \%$ dengan kriteria penilaian rendah, yang menunjukkan bahwa guru paling sedikit mengalami kesulitan ketika proses pembelajaran daring.

\section{Tabel 4}

Kesulitan Pada Indiktor Motivasi 


\begin{tabular}{lcc}
\hline \multicolumn{1}{c}{ Pertanyaan } & Persentase & Kriteria Hambatan \\
\hline $\begin{array}{l}\text { Guru memberikan pemahaman kepada siswa yang kurang } \\
\text { memahami materi pembelajaran }\end{array}$ & $50,53 \%$ & Setuju \\
\hline $\begin{array}{l}\text { Guru dapat berkomunikasi dengan baik kepada siswa ketika } \\
\text { pembelajaran daring sedang berlangsung }\end{array}$ & $25,26 \%$ & Setuju \\
\hline $\begin{array}{l}\text { Guru memberikan reward kepada siswa yang aktif dalam } \\
\text { pembelajaran daring }\end{array}$ & $42,10 \%$ & Setuju \\
\hline $\begin{array}{l}\text { Guru merumuskan tujuan pembelajaran daring yang harus } \\
\text { dicapai oleh siswa }\end{array}$ & $29,47 \%$ & Setuju \\
\hline Rata-rata & $36,84 \%$ & Rendah \\
\hline
\end{tabular}

Berdasarkan data dari Tabel 4 menunjukkan bahwa guru biologi merasa kesulitan dari indikator motivasi dengan persentase sebesar $36,84 \%$ dengan kriteria penilaian cukup. Dengan $50,53 \%$ guru selalu memberikan pemahaman kepada siswa yang kurang memahami materi pembelajaran. 25,26\% guru dapat berkomunikasi dengan baik kepada siswa ketika pembelajaran daring sedang berlangsung. $42,10 \%$ guru setuju memberikan reward kepada siswa yang aktif dalam pembelajaran daring agar siswa termotivasi saat pembelajaran berlangsung. 29,47\% guru merumuskan tujuan pembelajaran daring yang harus dicapai oleh siswa.

\section{Tabel 5}

Kesulitan Pada Indikator Kreativitas

\begin{tabular}{lcc}
\multicolumn{1}{c}{ Pertanyaan } & Persentase & Kriteria Hambatan \\
\hline $\begin{array}{l}\text { Guru menggunakan metode tanya jawab dalam proses } \\
\text { pembelajaran daring }\end{array}$ & $33,68 \%$ & Setuju \\
$\begin{array}{l}\text { Guru dapat mengatasi permasalahan siswa yang sulit dalam } \\
\text { memahami materi pelajaran yang telah diajarkan }\end{array}$ & $22,10 \%$ & Ragu-ragu \\
\hline Rata-rata & $27,89 \%$ & Rendah \\
\hline
\end{tabular}

Berdasarkan data dari Tabel 5 menunjukkan bahwa guru biologi merasa kesulitan dari indikator krativitas dengan persentase sebesar 27,89\% dengan kriteria penilaian rendah. 33,68\% guru setuju menggunakan metode tanya jawab dalam proses pembelajaran daring. 22,10\% guru ragu-ragu saat mengatasi permasalahan siswa yang sulit dalam memahami materi pelajaran yang telah diajarkan.

\section{Tabel 6}

Kesulitan Pada Indikator Sarana dan Prasarana

\begin{tabular}{lcc}
\hline \multicolumn{1}{c}{ Pertanyaan } & Persentase & Kriteria Hambatan \\
\hline $\begin{array}{l}\text { Guru menggunakan sarana dan prasarana yang } \\
\text { disediakan oleh pihak sekolah, seperti komputer, in }\end{array}$ & $29,47 \%$ & Setuju \\
$\begin{array}{l}\text { focus dan lain-lain } \\
\text { Guru memiliki kuota internet atau jaringan internet } \\
\text { yang memadai dalam melakukan proses pembelajaran } \\
\text { daring }\end{array}$ & $47,36 \%$ & Sangat Setuju \\
\hline Rata-rata & & \\
\hline
\end{tabular}

Berdasarkan data dari Tabel 6 menunjukkan bahwa guru biologi merasa kesulitan dari indikator sarana dan prasarana dengan persentase 34,20\% dengan kriteria penilaian rendah. 29,47\% guru setuju jika kesulitan untuk menggunakan sarana dan prasarana yang disediakan oleh pihak sekolah, seperti komputer, in focus, dan lain-lain. 47,36\% guru sangat setuju untuk memiliki kuota internet atau jaringan internet yang memadai dalam melakukan proses pembelajaran daring.

\section{Tabel 7}

Persentase Kesulitan Guru Biologi Setiap SMA Negeri Kota Lubuklinggau 


\begin{tabular}{lll}
\hline \multicolumn{1}{c}{ Nama Sekolah } & \multicolumn{1}{c}{ Persentase kesulitan } & \multicolumn{1}{c}{ Kriteria } \\
\hline SMA Negeri 1 Lubuklinggau & $100-86=14 \%$ & Rendah Sekali \\
\hline SMA Negeri 2 Lubuklinggau & $100-64=36 \%$ & Rendah \\
\hline SMA Negeri 4 Lubuklinggau & $100-69=31 \%$ & Rendah \\
\hline SMA Negeri 5 Lubuklinggau & $100-73=27 \%$ & Rendah \\
\hline SMA Negeri 6 Lubuklinggau & $100-72=28 \%$ & Rendah \\
\hline SMA Negeri 7 Lubuklinggau & $100-69=31 \%$ & Rendah \\
\hline SMA Negeri 8 Lubuklinggau & $100-78=22 \%$ & Rendah \\
\hline
\end{tabular}

\section{Persentase Kesulitan}

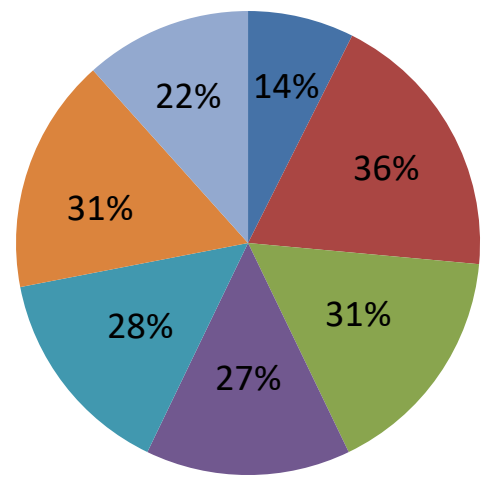

SMA NEGERI 1

- SMA NEGERI 2

SMA NEGERI 4

SMA NEGERI 5

SMA NEGERI 6

SMA NEGERI 7

SMA NEGERI 8

Gambar 2. Diagram Persentase Kesulitan Guru Biologi di setiap SMA Negeri Kota Lubuklinggau

Persentase kesulitan guru biologi setiap SMA Negeri Kota Lubuklinggau hanya mengalami sedikit kesulitan. Persentase paling rendah terdapat di SMA Negeri 1 Lubuklinggau dengan persentase $14 \%$ berkriteria rendah sekali dari penskoran angket, sedangkan persentase paling tinggi pada SMA Negeri 2 Lubuklinggau yakni dengan persentase 36\% berkriteria rendah. Berdasarkan penjelasan di atas menunjukkan bahwa kesulitan mengajar guru biologi di SMA Kota Lubuklinggau yang dijadikan tempat penelitian hanya mengalami sedikit kesulitan dengan persentase tertinggi hanya sebesar 36\% dengan kriteria rendah dikarenakan yang menjadi kesulitannya yaitu jaringan, waktu dan memberikan metode yang tepat saat proses pembelajaran. Setiap SMA Negeri hanya mengalami sedikit kesulitan hambatan tersebut telah mencakupi setiap indikator pada angket media, sikap, motivasi, kreativitas, dan sarana prasarana, serta hasil wawancara bahwa guru mengalami kesulitan dalam memahami siswa selama pembelajaran daring, menentukan metode yang tepat untuk pembelajaran agar siswa tidak merasa bosan, dalam hal ini guru dituntut untuk kreatif serta menentukan ide-ide pembelajaran yang tepat dan jaringan yang terkadang menghilang seperti halnya kehabisan kuota atau jaringannya gangguan saat proses pembelajaran berlangsung.

Faktor kesulitan mengajar pada guru ketika dalam pembelajaran berlangsung selama masa pandemi Covid-19 menurut Jayanti (2019), yaitu yang pertama pada sarana dan prasarana merupakan semua perangkat yang dapat secara langsung digunakan saat proses pendidikan di sekolah, seperti buku, perpustakaan, ruangan, laboratorium, alat pratikum, dan media pembelajaran, faktor kedua yaitu metode pembelajaran adalah suatu cara saat mengajarkan topik tertentu dan topik yang diajarkan dapat diterima oleh siswa dengan mudah dan dapat mencapai tujuan yang telah ditetapkan, dan faktor ketiga penguasaan materi harus menyiapkan dan merancang bahan ajar atau materi pelajaran dalam pelaksanaan kegiatan pembelajaran. Agar proses pembelajaran dapat berjalan dengan lancar, tidak ada kendala, berlangsung dengan baik, rancangan dan penyiapan bahan ajar harus cermat, baik dan sistematis. Menurut Santosa (2020) faktor kesulitan yang tertera pada setiap sekolah adalah siswa, guru dan orang tua mengalami kesulitan dalam proses belajar 
mengajar adanya sinyal yang hilang, harga kuota internet kurangnya komunikasi antara guru dan siswa serta penguasaan penggunaan aplikasi secara online.

\section{KESIMPULAN}

Berdasarkan hasil penelitian kesulitan guru biologi mengajar di SMA Negeri Kota Lubuklinggau selama masa pandemi Covid-19 adalah yang paling rendah mengalami sedikit kesulitan terdapat pada guru SMA Negeri 1 Lubuklinggau dengan persentase $14 \%$ dan SMA Negeri 2 Kota Lubuklinggau memiliki persentase kesulitan paling tinggi dengan 36\%. Penilaian setiap persentase guru biologi di SMA Negeri Lubuklinggau diatas telah mencakup dari indikator media, indikator sikap, indikator motivasi, indikator kreativitas dan indikator sarana prasarana.

\section{DAFTAR PUSTAKA}

Ahmad, I. F. (2020). Alternatif Assesment In Distance Lerning In Emergencies Spread Of Coronavirus Disease (Covid-19). Jurnal Pedagogik, 07(01), 195-222.

Amar's, I. P. I. (2020). Analisis Kendala dan Alternatif Pembelajaran Biologi Pada Masa Pandemi Covid-19 di SMA Swasta Yapim Taruna Dolok Masihul. Skripsi. Sumatera Utara: UIN

Amirullah, G., \& Irdalisa. (2020). Pelatihan Kemampuan TpACK Pasca Pandemi Covid-19 Bagi Guru Biologi SMA Muhammadiyah se-DKI Jakarta. Jurnal Prosiding Seminar Nasional Abdimasmu. 1(2).

Arikunto, S. (2010).Prosedur penelitian Suatu Pendekatan Praktik. Jakarta: PT Rhineka Cipta.

Arikunto, S. (2013).Prosedur Penelitian Suatu Pendekatan Praktek. Jakarta: PT Bumi Aksara.

Basilaia, G., \& Kvavadze, D. (2020). Transition to Online education in Schools During a SARSCoV-2 Coronavirus (Covid-19) Pandemi in Georgia. Pedagogial Research, 5(4), em0060. https://doi.org/10.29333/pr/7937.

Handarini, O. I., \& Wulandari, S. S. (2020). Pembelajaran Daring Sebagai Upaya Study From Home (SFH). Jurnal Pendidikan Administrasi Perkantoran (JPAP), 8(1), 496-503.

Irwanto \& Irwani.(2017). Profil Karakteristik dan Kompetensi Guru Biologi SMA Negeri 1 Bajodi Era Revolusi Industri 4.0.Jurnal Biologi dan Pembelajarannya, 14(2), 62-81

Jayawardana, H. B. A., Sugiarti, R., \& Gita. D. W. I. (2020). Inovasi Pembelajaran Biologi di Era Evolusi Industri 4.0 (Issue September. Pp. 58-66).

Jayanti, M. I. (2018). Faktor Kesulitan Guru Melaksanakan Pembelajaran Materi Struktur dan Fungsi Sel di SMA Negeri Se-Kota Bima. Oryza jurnal Pendidikan Biologi, 7(2), 94-98

Menteri Pendidikan. (2020). Surat Edaran Nomor 2 tahun 2020 Tentang Pencegahan dan Penanganan Covid-19 diLingkungan Kemendikbud dan Surat Edaran Nomor 3 Tahun 2020.

Santosa, A.T,, \& Lufri, Zulyusri. (2020). Problematika Dalam Pembelajaran Berbasis Virtual Learning Environment (VLE) Terhadap Siswa dan Guru SMA/MA Pada Materi Biologi di Masa Covid-19. Journal on Education, 3(1), 93-103 
Saifulloh, A. M., \& Darwis, M. Dalam Meningkatkan Efektifitas Proses Belajar Mengajar di Masa Pandemi Covid-19.Bidayatuna, 3(2), 286-311.

Sugiyono. (2014). Metode Penelitian Kuantitatif, Kualitatif, dan R\&D. Bandung: ALBETA.

Supriyatin, T. (2020). Analisis Pembelajaran Filsafat MIPA Berbasis Daring pada Mahasiswa Pendidikan Biologi di Era Pandemi Covid-19 yang digunakan oleh guru. Titin Supriyatin, 1(1), 18-21.

Riastuti, D.R. \& Yuli. F. 2021. Studi Dokumenter Hasil Belajar Psikomotorik Siswa SMA Pada Materi Sistem Pernapasan Melalui Model Pembelajaran Project Based Learning (PJBL). Jurnal Pendidikan Biologi dan Sains, 4(1), 93-98

Word Health Organization.(2019). Coronavirus. Retrieved From World health Prganization: https://www.who.int/health-topics/coronavirus 